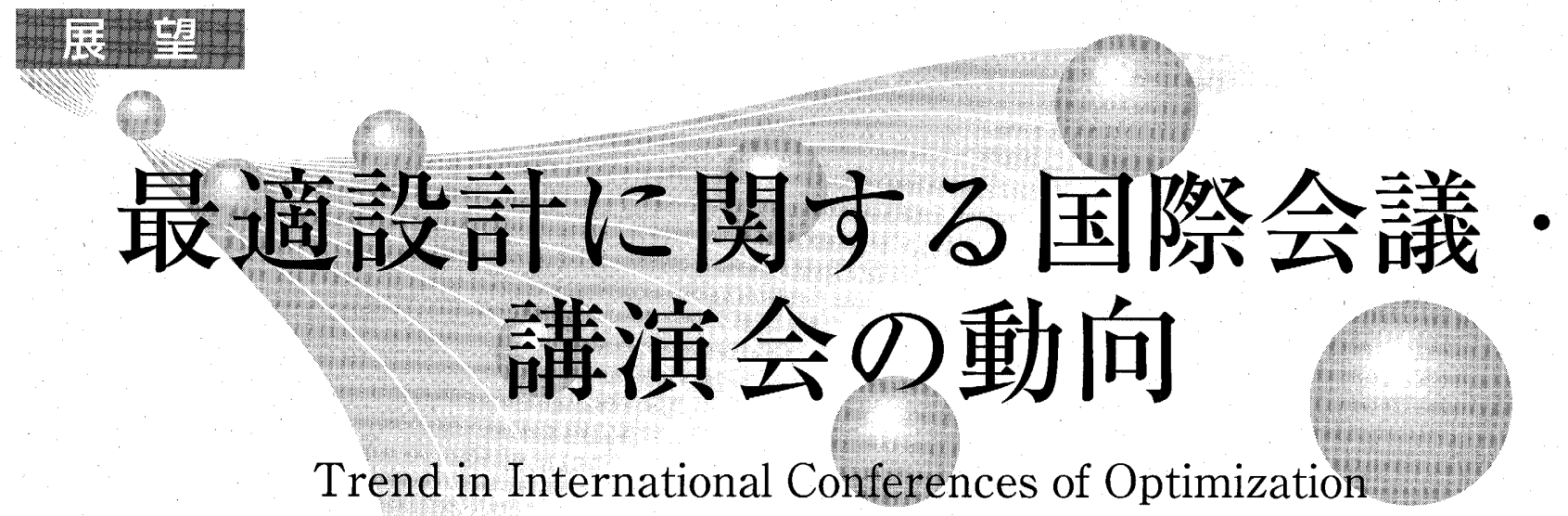

執筆者プロフィール

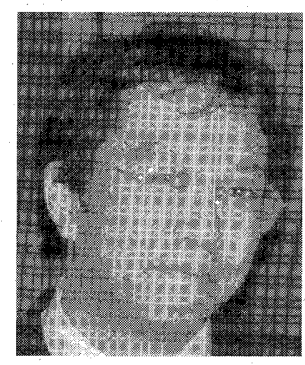

\section{荒川 雅生}

\section{Masao ARAKAWA}

1993 年早稲田大学大学院後期博士課程修了, 早稲田大学助手, 東京工業大学 JR 東日本寄附 講座助教授などを経て, 1999 年から現職

○研究・尃門テーマは最適化を通じた設計方法 論

○正員, 香川大学助教授 工学部 信頼性情報 システム工学科

( ( 761-0396 高松市林町23217-20／

E-mail:arakawa@eng.kagawa-u.ac.jp)
最適設計は横断的なシステム技術であり，分野を問わず にさまざまな利用のされ方をしてきている，従来からの構 造の最適化, 形状の最適化, トポロジーの最適化, 非線形 応答に対する最適化, 熱流体, 電磁気の最適化, ロバスト 設計，信頼性設計，そして，複合領域の最適化への応用は 目覚しいものがある。これをべースとして，大規模問題へ の適用を図る研究が底流にある。
ここでは，ここ数年間に開催された，いくつかの国際会 議の内容の変遷を紹介したい. ISSMO（International Society of Structural and Multidisciplinary Optimization）が主催す る. WCSMO (World Congress of Structural and Multidisiplinary Optimization）(奇数年の隔年開催），アメリ力航空宇宙 学会（AIAA）が主催する MAO（Multidisciplinary Analysis and Optimization）（偶数年の隔年開催），アメリカ機械学会 が主催する IDETC (International Design Engineering Technical Conference) (毎年開催), そして, 近年, 設計工学シス テム部門が日本側の主体となって行われている日中韓の構 造および機械システムの最適化シンポジウム（偶数年の隔 年開催：2004 年金沢) の内容加見てみる。

最初に, WCSMO の 5 回目（2003）と6回目 (2005) の 比較から，傾向を見てみたい。分類としては，近似を含む アルゴリズムの開発 $(8.9 \% \rightarrow 10.2 \%)$, 進化的な手法 $(5.4 \% \rightarrow 4.2 \%)$, 逆問題 $(5.4 \% \rightarrow 14.0 \%)$, ロバスト・信頼 性設計 $(7.1 \% \rightarrow 6.7 \%)$, 形状最適化 $(3.6 \% \rightarrow 6.0 \%)$, トポ ロジー最適化 $(10.7 \% \rightarrow 0.7 \%)$, その他応用に分けてみる。 開催地, 参加者の影響もあるかもしれないが, トポロジー 最適化に関するものが多少減ってきている。たたし，セッ ションとしての構成がなかっただけで応用分野としては利 用されている。バイオ関連の最適化がまとまったセッショ ンとして新たに入ってきている。遺伝的アルゴリズムや進 化的アルゴリズムの国際会議である GECCO (Genetic and Evolutionary Computation COnference) などでもバイオ関 連, 医学との連携にかかわる諸問題を最適化を通じて問題 を解決したり，パラメータを同定する研究の動きはでてき ている. 解析技術の進歩も手伝っているのであろうが，今 後さらに注目される分野である。応用分野としては， 
MEMS（Micro Electro Mechanical Systems）の構成に最適 化を利用しようとする動向も見られる。当初は単純に最適 化を利用してみたというものが, 徐々に実用的なレベルで 利用されてきている。

多目的最適化のセッションができている。セッションに は入っていないが，多目的最適化の手法が利用されている 論文も増えてきている。多目的最適化が盛んになってきた と考えるのは時期尚早かもしれないが，傾向として問題を 多角的にとらえて，最適化を通じて意思決定しょうという 方向性は出てきている.MAOを含めて考えると, 手法論 としての複合領域の最適化に関する論文は減ってきてい る. その一方で応用面の論文が増えてきている．近似最適 化の関連では，応答曲面法が手法としてある程度確立され てきたこともあり，基礎的な検討から応用段階に入ってき ている。また, 応答曲面の生成方法として, 流行した Kriging 法で用いた確率分布を基に，どの点を追加データ として解析をすればよいのかを検討したものや，それをさ らに応用して大域的な最適化問題を解くための手法として 拡張しているものもある。また，近似手法としてニューラ ルネットワークの一種である RBF（Radial Basis Function） を利用する動きも広がってきている。この種の近似最適化 手法によって，大局的な最適解の近傍に解を求めること は, 確かに可能であるが，一般的に大局的な最適化手法と して有効な手法であると断定できるわけではない，アルゴ リズム面では，ここ数年, PSO (Partcle Swarm Optimization）が盛んに取り上げられている.この手法は遺伝的ア ルゴリズムのように集団を構成し，集団の動き方を簡単な 漸化式に入れることで比較的早期に良好な解に行き着くこ とができる方法であり，1997年にKennedyらが開発して以 来, パラメータの設定方法をはじめ, 離散変数への拡張な どさまざまな観点から検討がなされている。 AIAA では, 大域的な最適化手法として，あるいは，パラメー夕同定方 法として，場合によっては平衡方程式を解くための手段と して利用されている。基礎的な理論が遺伝的アルゴリズム よりも簡易であり, 同程度の応用性を持うことから, 今後 さらに改良，基礎的な検討がなされていくものと思われ b.

ASME を中心に製品系列の最適化問題がここ数年盛んに 取り上げられている。これは, Product Familyとか, Product Platform というセッション名になって開催されており， 毎年 2,3 セッションが組まれている，基本的には単一の
製品開発をするのではなく，製品系列として共通の部品 をより多く取り入れるための設計手法の確立を目的とし ている。その中で最適化を利用しようとしている。この ほか，工学的な設計には工学的な要因ばかりではなく， 市場の動向を取り入れること見ながら目標を定めて設計 していくことの重要性が説かれている．手法の基本的な 構成は複合領域の最適化手法と同様である.しかしなが ら，その最上位に市場の動向を置いている。サブプログ ラムとして従来の工学的な要素が並ぶ形になっている. 市場の動向をとり入れると当然の結果として多目的最適 化になる。また，市場動向の要因は簡単に数值化できな いので，近似関数で代用している。このように，概念の 実現へ向けた説明付けのツールとして最適化を積極的に 利用しようという動向は今後ともに強まっていくであろ うと思われる。アメリカ自動車学会では, FOA（First Order Analysis）のセッションが構成されている．FOA は設 計者が把握用意である簡易な解析をベースに，自分たち が考えていることを実現するためのツールとしてやはり 最適化を利用している.この種の最適化の利用は，従来 までの底流にあった最適化の結果を直接使うだけではな い新しい傾向と捕らえることができる。

日中韓で行われる構造および機械システムの最適化シン ポジウムCJK-OSM (China-Japan-Korea Joint Symposium on Optimization of Structural Mechanical Systems）は，偶数年に 3 箇国持ち回りで開催される。他の国際会議と異なる点 は，参加者が3箘国に限定されていることもあり，若手の 研究者が積極的に参加している点である。2004 年に金沢 で開催されたときには，160名の参加で約 150 件の発表が 行われている。またこの会議では機械系にとどまらず， 航空宇宙, 土木, 建築, 電気, 計算工学分野に参加者がま たがっている，大まかに言えば，韓国内の研究の動きが活 発であり，アメリカと同じように市販のソフトウェアを ツールとして，応用面に生かす祭にどのような工夫をする かという研究に傾いている. 国際会議への参加も積極的で あり，今後どのような方向に進めていくのか注目していき たい，中国では，その種のソフトウェアが導入しづらいの か, どちらかというと理論的なアプローチが主流である. その中間くらいに，日本の研究者の研究対象と動向がある ように思われる。

（原稿受付 2006 年 3 月 17 日） 